\title{
NUTRIENTS AND CHEMICAL OXYGEN DEMAND (COD) REMOVALS BY MICROALGAE-BACTERIA CO-CULTURE SYSTEM IN PALM OIL MILL EFFLUENT (POME)
}

\author{
Amirah Samsudin, Azlin Suhaida Azmi, Mohd Nazri Mohd Nawi, \\ Amanatuzzakiah Abdul Halim* \\ Department of Biotechnology Engineering, Kulliyyah of Engineering, \\ International Islamic University Malaysia. \\ P.O. Box 10, 50728 Kuala Lumpur, Malaysia, \\ "Corresponding author: amana@iium.edu.my
}

(Received: $3^{\text {rd }}$ April 2019; Accepted: $11^{\text {th }}$ July 2019; Published on-line: $2^{\text {nd }}$ December 2019)

\begin{abstract}
In Malaysia, large amounts of waste known as palm oil mill effluent (POME) are generated during the production process of crude palm oil. Conventionally, POME is treated using biological treatment that involves two processes; aerobic and anaerobic. These processes however, require long hydraulic retention time and produce methane and carbon dioxide $\left(\mathrm{CO}_{2}\right)$ that can cause environmental problems. Alternatively, POME can be treated by a combination of microalgae and bacterial co-culture that requires a shorter treatment time and is environmentally friendly. In this study, a microalgae strain, Chlorella vulgaris was co-cultured with a bacteria strain Azospirillum brasilense in POME with an initial concentration of $1.9 \times 10^{6}$ cells $/ \mathrm{mL}$ and $10^{4} \mathrm{CFU} / \mathrm{mL}$, respectively. The removal of chemical oxygen demand (COD) and nutrients (phosphorus and ammonium) were analyzed using Standard Methods, APHA 1999. The effectiveness of the co-culture system in POME treatment under agitation and aeration conditions for nutrients and COD removals were studied. Results show that the removal of ammonium by microalgae was much higher under the aeration condition (73.5\%) compared to that of the agitation condition (34.4\%) in POME. Moreover, co-culture system exhibits better removal of ammonium, phosphorus, and COD $(84 \%, 87.3 \%$ and $51.8 \%$, respectively) compared to that in an axenic microalgae system $(67 \%, 84.2 \%$ and $41.1 \%$, respectively). The kinetic studies on the co-culture system and the nutrients removal were also conducted. The kinetic coefficients of maximum specific growth rate $\left(\mu_{\max }\right)$ and half-saturation coefficient $\left(k_{s}\right)$ obtained from Lineweaver-Burk plot were $0.192 \mathrm{~d}^{-1}$ and $27.32 \mathrm{mg} / \mathrm{L}$, respectively. Based on the findings obtained, the co-culture system could be implemented as an efficient and inexpensive alternative method for POME treatment.
\end{abstract}

ABSTRACT: Di Malaysia, banyak bahan buangan kilang minyak kelapa sawit yang dikenali sebagai (POME) telah terhasil ketika proses penghasilan minyak kelapa sawit mentah. Dahulu, POME dirawat menggunakan rawatan biologi yang terdiri daripada dua proses; erob dan anaerob. Walau bagaimanapun, proses-proses ini memerlukan masa yang panjang bagi pengekalan hidraulik dan gas metana dan karbon dioksida $\left(\mathrm{CO}_{2}\right)$ telah terhasil yang menyebabkan masalah alam. Sebagai alternatif, POME dapat dirawat dengan kombinasi mikroalga dan sistem bakteria ko-kultur melalui masa rawatan yang lebih pendek dan mesra alam. Kajian ini, strain mikroalga, Chlorella vulgaris telah di ko-kultur dengan strain bakteria Azospirillum brasilense dalam POME dengan ketumpatan awal $1.9 \times 10^{6} \mathrm{sel} / \mathrm{mL}$ dan $10^{4} \mathrm{CFU} / \mathrm{mL}$ masing-masing. Penyingkiran kehendak oksigen secara kimia (COD) dan nutrisi (fosferus dan ammonium) telah dikaji menggunakan Kaedah Biasa, APHA 1999. Keberkesanan system ko-kultur dalam rawatan 
POME di bawah keadaan kisaran dan pengudaraan bagi nutrisi dan penyingkiran COD telah diselidiki. Dapatan kajian menunjukkan penyingkiran ammonium menggunakan mikroalga lebih banyak melalui keadaan pengudaraan (73.5\%) berbanding keadaan kisaran (34.4\%) dalam POME. Tambahan, system ko-kultur menunjukkan lebih bagus dalam penyingkiran ammonium, fosferus dan COD (84\%, 87.3\% dan 51.8\%, masingmasing) dibandingkan dengan sistem mikroalga aksenik (67\%, 84.2\% dan 41.1\%, masingmasing). Kajian kinetik pada sistem ko-kultur dan penyingkiran nutrisi turut dijalankan. Pekali kinetik kadar maksimum pertumbuhan sebenar $\left(\mu_{\max }\right)$ dan pekali separuh-penepuan $\left(k_{s}\right)$ telah diperolehi melalui plot Lineweaver-Burk iaitu $0.192 \mathrm{~d}^{-1}$ dan $27.32 \mathrm{mg} / \mathrm{L}$, masingmasing. Berdasarkan penemuan ini, sistem ko-kultur boleh dijalankan dengan cekap dan murah sebagai pilihan alternatif kepada rawatan POME.

KEYWORDS: co-culture; microalgae; palm oil mill effluent; symbiotic; wastewater treatment

\section{INTRODUCTION}

Malaysia is one of the largest producers and exporters of palm oil in the world. During the palm oil production process, huge amounts of wastewater, known as palm oil mill effluent (POME) consisting of various pollutants and nutrients, are generated [1]. POME contains a high concentration of phosphorus, organic nitrogen, and other nutrients. Moreover, the biochemical oxygen demand (BOD) and chemical oxygen demand (COD) content in POME are also high, reaching 100 times higher than municipal sewage [2]. Hence, POME treatment is very crucial prior to discharge into natural water resources, such as rivers, which can cause water pollution and negatively affect aquatic life.

POME has been treated using conventional methods (e.g. anaerobic and aerobic digestion). However, these methods produce $\mathrm{CO}_{2}$ and methane which can lead to enviromental problems. Furthermore, these conventional methods require long hydraulic retention time (HRT) and can take at least 20 days for the aerobic digestion process. As an alternative for POME treatment, utilization of microalgae has been introduced due to its ability to grow in robust environments and still remove various pollutants in wastewater such as phosphorus and nitrogen. It was also reported that bacteria known as microalgae growth promoting bacteria (MGPB) can be co-cultured with microalgae to improve the removal of nutrients [3-6]. Moreover, this co-culture system shares a symbiotic relationship. The oxygen $\left(\mathrm{O}_{2}\right)$ produced by microalgae during photosynthesis will be used by heterotrophic bacteria and the bacteria in return release $\mathrm{CO}_{2}$ that can be consumed by microalgae for growth [7].

The aim of this study is to evaluate the efficiency of microalgae and bacteria species, Chlorella vulgaris and Azospirillum brasilense for nutrients (ammonium and phosphorus) and COD removals in partially treated POME under different cultivation conditions to replace the aerobic digestion process in the conventional POME treatment. The kinetics studies of the co-culture system were also determined.

\section{METHODOLOGY}

\subsection{Raw Materials and Inoculum Preparation}

A species of microalgae (Chlorella vulgaris) and a bacteria strain (Azospirillum brasilense) were used in this study. The microalgal strain and bacteria were purchased from Universiti Malaya, Kuala Lumpur and Leibniz-Institute DSMZ, Germany respectively. Microalgae was grown in Tris-Acetate-Phosphate (TAP) medium at $25{ }^{\circ} \mathrm{C}$ and $150 \mathrm{rpm}$ in a rotary shaker and bacteria was maintained in nutrient media at $30 \pm 2{ }^{\circ} \mathrm{C}$ and $120 \mathrm{rpm}$ [3]. Partially treated palm oil mill effluent (POME) (sample after anaerobic process) was 
collected from West Mill Sdn Bhd, Sime Darby Research Centre, Carey Island, Malaysia. Partially treated POME was used because this study aims to replace the aerobic process and the amount of nutrients available were acceptable for microalgae to growth. Sample obtained was stored in $5 \mathrm{~L}$ plastic containers and kept at $4{ }^{\circ} \mathrm{C}$ to limit the activity of biodegradation process and prevent any contamination [7]. The ammonium, phosphorus and COD contents in partially treated POME are 162, 18, and $874 \mathrm{mg} / \mathrm{L}$, respectively.

\subsection{Experimental Set Up}

Microalgae and bacteria were cultivated in POME at $10 \%$ concentration $\left(\mathrm{V}_{\text {microalgae - }}\right.$ bacteria $/ \mathrm{V}_{\text {POME }}$ ) in a $250 \mathrm{~mL}$ flask for 6 days and $25 \pm 2{ }^{\circ} \mathrm{C}$ under $45-50 \mu \mathrm{mol}$ photon $\mathrm{m}^{-2} \mathrm{~s}^{-1}$ of illumination of white fluorescent light (alternate $12 \mathrm{~h} / 12 \mathrm{~h}$ of light/dark periods) [7]. The initial concentrations of microalgae and bacteria were $1.9 \times 10^{6}$ cells $/ \mathrm{mL}$ and $10^{4} \mathrm{CFU} / \mathrm{mL}$ respectively [7].

Two different cultivation conditions of microalgae - bacteria for POME treatment, agitation and aeration conditions, were tested. For the agitation condition, POME treatment was incubated in incubator shaker at $25^{\circ} \mathrm{C}$ and $150 \mathrm{rpm}$. For the aeration condition, a shake flask containing POME and microbes was connected to an air pump $(1.8 \mathrm{~L} / \mathrm{min})$ to provide aeration to the treatment system. A sterilized $0.22 \mu \mathrm{m}$ nylon filter was used to avoid contamination. During cultivation, $2 \mathrm{~mL}$ of algae suspension was collected for every 2 days and filtered using $0.45 \mu \mathrm{m}$ nylon filter before it was analyzed for ammonium, phosphorus and COD using their respective method. The growth of microalgae and bacteria were also recorded.

\subsection{Analytical Methods}

Microalgae cell number was calculated by Neubauer haemocytometer counting and bacterial concentrations were determined as colony forming units (CFU) on nutrient media agar plates. Besides that, the Standard Methods for the Examination of Water and Wastewater were used to analyse ammonium, phosphorus and COD removal [8]. Ammonium content was analysed using phenate method while phosphorus content (ortophosphate) was analysed using ascorbic acid method and COD was analysed using closed reflux, colorimetric method [7].

\subsection{Kinetics Study}

Based on the best growth conditions (agitation or aeration) in terms of COD and nutrient removal, batch kinetics studies were carried out by using approximately $1.9 \times 10^{6}$ cells $/ \mathrm{mL}$ and $10^{4} \mathrm{CFU} / \mathrm{mL}$ of microalgae and bacteria initial concentration, respectively. They were cultivated in partially treated POME at room temperature $\left(25 \pm 2{ }^{\circ} \mathrm{C}\right)$. POME was diluted to study the kinetics of different N/P ratios. The removals and the growth of microalgae were recorded and analyzed for six days of treatment. Kinetics coefficient, maximum specific growth rate, $\mu_{\max }\left(\mathrm{d}^{-1}\right)$ and half-saturation coefficient, $k_{s}(\mathrm{mg} / \mathrm{L})$ were determined using Lineweaver-Burk plot of $1 / \mu$ vs. $1 / S$.

\section{RESULTS AND DISCUSSION}

\subsection{POME Treatment in Agitation and Aeration Conditions}

The characteristic of the partially treated POME sample collected is tabulated in Table 1. 
Table 1: Characteristic of partially treated POME

\begin{tabular}{ccc}
\hline Parameters & $\begin{array}{c}\text { Concentration } \mathbf{( m g / L ) ,} \\
\text { except for } \mathbf{p H} \text { and turbidity }\end{array}$ & $\begin{array}{c}\text { Average Concentration } \\
(\mathbf{m g} / \mathbf{L})\end{array}$ \\
\hline $\mathrm{pH}$ & $7.5-8.5$ & 8 \\
$\mathrm{COD}$ & $600-900$ & 750 \\
Ammonium & $160-250$ & 205 \\
Phosphorus & $10-30$ & 20 \\
Total Suspended Solid & $1120-1160$ & 1140 \\
Total Volatile Solid & $880-1170$ & 1025 \\
Turbidity (NTU) & $2755-2785$ & 2775 \\
Oil and Grease Content & $118-234$ & 176 \\
\hline
\end{tabular}

In this study, microalgae were grown in non-sterilized partially treated POME under agitation and aeration cultivation conditions. Throughout the treatment, the $\mathrm{pH}$ of POME was observed and measured. At day 0 , the $\mathrm{pH}$ of POME samples was 7.5 and it increased to 8.8 after six days of treatment in both conditions. The percentage of ammonium, phosphorus, and COD removal by agitation and aeration conditions in non-autoclaved partially treated POME are illustrated in Fig. 1.

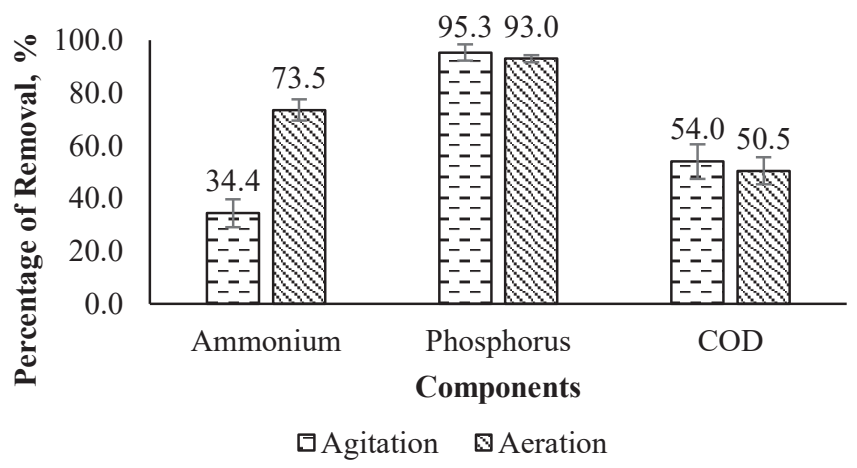

Fig. 1: Percentage of ammonium, phosphorus, and COD removal in agitation and aeration conditions by axenic microalgae in a $250 \mathrm{~mL}$ flask containing $150 \mathrm{~mL}$ nonsterilized partially treated POME with $10 \%$ concentration $\left(\mathrm{V}_{\text {microalgae }- \text { bacteria }} / \mathrm{V}_{\mathrm{POME}}\right)$ for 6 days at $25 \pm 2{ }^{\circ} \mathrm{C}$ and under $45-50 \mu \mathrm{mol}$ photon $\mathrm{m}^{-2} \mathrm{~s}^{-1}$ of illumination of white fluorescent light (alternate $12 \mathrm{~h} / 12 \mathrm{~h}$ periods of light/dark). Initial concentration of Ammonium $=162$ $\mathrm{mg} / \mathrm{L}$, Phosphorus $=18 \mathrm{mg} / \mathrm{L}$ and COD $=874 \mathrm{mg} / \mathrm{L}$. Error bars represent one standard deviation about the mean $(n=3)$.

Based on Fig. 1, the removal of ammonium in aeration condition is $73.5 \%$ which is higher compared to that in agitation condition which is $34.4 \%$. The ammonium removal percentage was in line with the growth rate of $C$. vulgaris which were $0.356 \mathrm{~d}^{-1}$ and 0.176 $\mathrm{d}^{-1}$ for aeration and agitation system respectively. Similar results were obtained whereby the microalgae cultivated with air supply (aerated) recorded higher growth rate compared to the microalgae grown in mixing shaker (non-aerated system) [9]. The optimum turbulence effect created by aeration system promotes better cell growth which consequently helps in the removal of the nutrients. Moreover, under equal light intensity, air flux is produced as a result of the turbulence and creates different movement regimes of the cells within the media. Adequate turbulence enhances mass transfer of nutrients to the microalgae cell and 
promotes gas exchange that overcomes the photo-oxidative effect as well as minimizing thick boundary layer between microalgae cell and the surrounding condition of unstirred suspension. In addition to that, sufficient system turbulence enhances the microalgae reproduction compared to the non-aerated medium, which can cause biomass accumulation [9].

Although the removals of phosphorus and COD in the agitation system were higher compared to those in the aeration system, the difference was very small, i.e. less than $5 \%$. Results indicated that the aeration system offered better nutrient removal especially for ammonium removal. Therefore, the aeration system was chosen to be used in the subsequent experiment.

\subsection{Axenic and Co-culture Systems in Aeration Condition}

A co-culture system ( $C$. vulgaris and A. brasilense) was utilized in the partially treated POME treatment. In this case, sterilized partially treated POME was used with initial concentration of $874 \mathrm{mg} / \mathrm{L}, 162 \mathrm{mg} / \mathrm{L}$ and $18 \mathrm{mg} / \mathrm{L}$ of COD ammonium and phosphorus, respectively. The microalgae - bacteria growth conditions were at $0.77 \mathrm{~g} / \mathrm{L}\left(1.9 \times 10^{6}\right.$ cells $/ \mathrm{mL}), 10^{4} \mathrm{CFU} / \mathrm{mL}$ and day 1.52 for microalgae initial concentration, bacteria initial concentration and bacteria inoculation time, respectively. POME treatment was conducted in the aeration condition. The growth profiles of microalgae - bacteria and percentage of nutrients and COD removals in axenic and microalgae - bacteria co-culture systems are shown in Fig. 2 (a) and 2 (b), respectively.

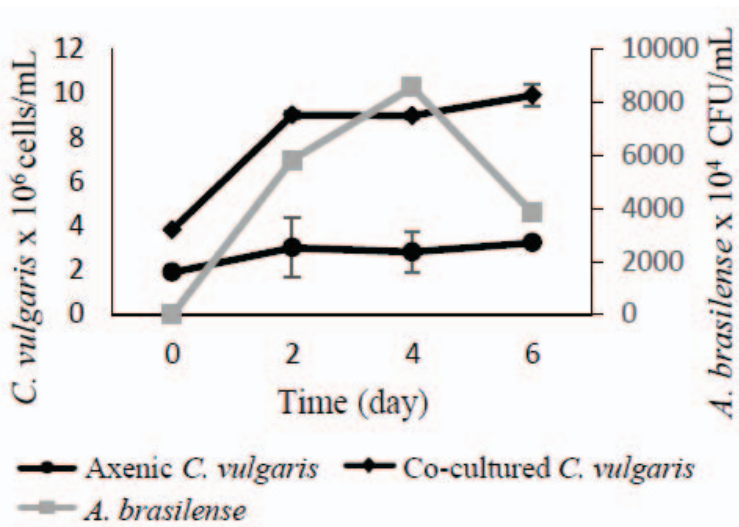

(a)

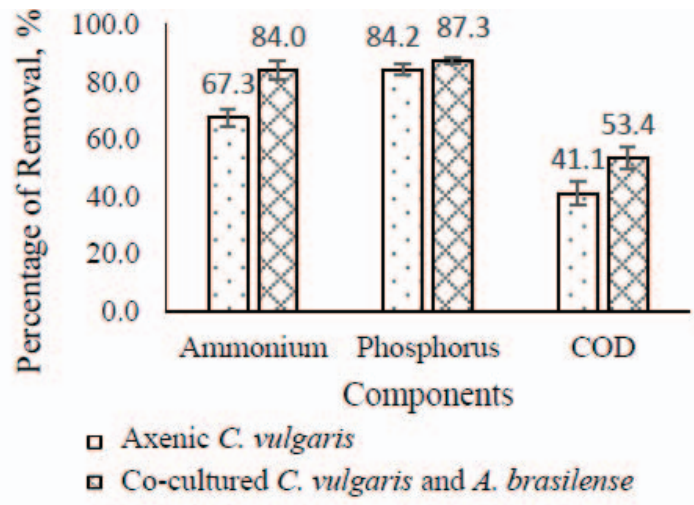

(b)

Fig. 2: (a) Growth profiles of bacteria (A. brasilense), microalgae (C. vulgaris) in axenic system and microalgae (C. vulgaris and A. brasilense) in co-culture system (b) Percentage of ammonium, phosphorus and COD removals in aeration condition by axenic microalgae and co-culture microalgae - bacteria in a $250 \mathrm{ml}$ flask containing $150 \mathrm{~mL}$ sterilized partially treated POME with $10 \%$ concentration $\left(\mathrm{V}_{\text {microalgae }- \text { bacteria/ }} / \mathrm{V}_{\text {POME }}\right)$ for 6 days at $25 \pm 2{ }^{\circ} \mathrm{C}$, under $45-50 \mu \mathrm{mol}$ photon $\mathrm{m}^{-2} \mathrm{~s}^{-1}$ of illumination of white fluorescent light (alternate $12 \mathrm{~h} / 12 \mathrm{~h}$ periods of light/dark) and aerated. Initial concentration of Ammonium $=162 \mathrm{mg} / \mathrm{L}$, Phosphorus $=18 \mathrm{mg} / \mathrm{L}$ and COD $=874 \mathrm{mg} / \mathrm{L}$. Error bars represent one standard deviation about the mean $(n=3)$.

Figure 2 (a) shows that, co-culture of microalgae and bacteria enhanced the microalgae population. The specific growth rate of co-cultured microalgae was higher $\left(0.570 \mathrm{~d}^{-1}\right)$, compared to that of axenic microalgae $\left(0.228 \mathrm{~d}^{-1}\right)$. Similar results were obtained by a study that reported that the growth of $C$. vulgaris was significantly enhanced when co- 
immobilized with $A$. brasilense bacteria under aeration conditions $(1.8 \mathrm{~L} / \mathrm{min})$ [3]. It was also reported that some bacteria species enhance microalgae cells growth [10]. However microalgae and bacteria have a complex relationship. It depends on the species of microlagae and bacteria as well as the growth conditions themselves [5,11]. Mutual symbiosis between microalgae and bacteria can be achieved if the species and conditions were optimum for both microorganisms. The results showed that bacteria promoted the growth of microalgae when the initial concentration was suitable $\left(10^{4} \mathrm{CFU} / \mathrm{mL}\right)$ and cultivated under aeration conditions. A study reported that, at low bacteria concentration $\left(10^{2} \mathrm{CFU} / \mathrm{mL}\right)$, the effect of bacteria in the co-culture system was not significant towards the removal of the nutrients. On the other hand, low nutrient removal was also recorded at maximum bacteria concentration $\left(10^{6} \mathrm{CFU} / \mathrm{mL}\right)$ due to the competition of the nutrients between the bacteria and microalgae. At these conditions, the bacteria growth rate was higher than the microalgae growth rate, hence the utilization of nutrients was dominated by the bacteria cells [7].

In addition, $A$. brasilense bacterium was able to grow well with microalgae and partially treated POME with specific growth rates of $2.264 \mathrm{~d}^{-1}$. Besides getting oxygen from the microalgae's photosynthesis process, the aeration process helps to promote gaseous exchange and enhances mass transfer of nutrients in the system. Moreover, excess oxygen from microalgae photosynthesis can be released from the media in the aeration system [10].

Based on Fig. 2 (b), the co-culture system has significantly increased the removals of COD and nutrients after six days of treatment, especially for ammonium and COD removal. The presence of bacteria delivers positive effect to the system. Higher percentage removals of ammonium, phosphorus and COD were obtained for co-cultured C. vulgaris system $(84 \%, 87.3 \%$ and $53.4 \%$, respectively) compared to that from axenic $C$. vulgaris system $(67.3 \%, 84.2 \%$, and $41.1 \%$, respectively). These results show better removals of COD and nutrients compared to another study that reported that microalgae from Chlamydomonas incerta species removed $67.35 \%$ of COD with initial concentration of $250 \mathrm{mg} / \mathrm{L}$ in POME in 28 days [1]. Ammonium removal in this study was sligthly lower (84\%) compared to the previous study, which used Spirulina plantesis to achieve $96.5 \%$ removal from approximately $296 \mathrm{mg} / \mathrm{L}$ of initial concentration [2]. Comparison of DOE standard and results of removals achieved by this study is presented in Table 2 .

Table 2: DOE standard B and final results of removals achieved by this study

\begin{tabular}{lcccc}
\hline & DOE & \multicolumn{3}{c}{ This Study } \\
\cline { 3 - 4 } & Standard B & $\begin{array}{c}\text { Initial } \\
\text { Concentration }\end{array}$ & \multicolumn{2}{c}{ Final Concentration } \\
\cline { 3 - 4 } & & $\begin{array}{c}\text { Axenic and Co- } \\
\text { cultured System }\end{array}$ & Axenic System & $\begin{array}{c}\text { Co-cultured } \\
\text { System }\end{array}$ \\
\hline COD (mg/L) & 200 & 874 & $514.8 \pm 37.32$ & $407.3 \pm 32.95$ \\
Ammonium (mg/L) & 20 & 162 & $53 \pm 4.97$ & $25.9 \pm 5.3$ \\
Phosphorus (mg/L) & $10^{*}$ & 18 & $2.84 \pm 0.39$ & $2.29 \pm 0.15$ \\
\hline
\end{tabular}

* DOE Standard B for sewage discharge into enclosed water body

Results obtained in this study showed that, microalgae - bacteria co-cultured system exhibits a good potential to be applied in POME treatment within six days of cultivation compared to aerobic digestion process that required at least 20 days of treatment with final concentration 200, 52 and $12 \mathrm{mg} / \mathrm{L}$ of COD, nitrogen and phosphorus respectively [1]. The co-cultured system also proves that, it enhances the COD and nutrient removal in the 
treatment compared to the axenic system. However, further investigation has to be conducted to improve COD removal in order to achieve the standard set by DOE, Malaysia, prior to discharge treated POME into the river. Heterotrophic bacteria is one of the microorganisms that have an important role in the reduction of COD content by breaking down the organic matter in the wastewater. Isolation and growth characterization of heterotrophic bacteria in partially treated POME sample could be investigated further in order to find more efficient bacteria to improve COD removals in POME.

\subsection{Kinetics Studies of Microalgae Growth and Nutrients Removal}

There are two important nutrients for microalgae growth: phosphorus $(\mathrm{P})$ and ammonium $(\mathrm{N})$. Kinetics constants were determined to study the rate of nutrients uptake by the microalgae. In this study, nutrients removal rates were calculated by Eq. (1) [12].

$$
R=\frac{C_{0}-C_{i}}{t_{i}-t_{0}}
$$

where $R$ represents the removal rate of nutrients $(\mathrm{N}$ or $\mathrm{P}), C_{0}$ and $C_{i}$ represent initial concentration of nutrients and nutrient concentration at time $t_{i}$ respectively and $t_{i}$ is the time when there is no significant change of nutrient concentration. The specific nutrient removal rate, $R_{i}$ was determined by dividing $R$ by the initial cell density (C. vulgaris). In these kinetic studies, two POME samples with different N/P ratio were utilized. The N/P ratio of media used for POME 1 and POME 2 were 8.96 and 2.27 respectively. The specific nutrient removal rate, $R_{i}$ of ammonium and phosphorus for both samples are shown in Table 3.

Table 3: Specific nutrient removal rate of ammonium and phosphorus in POME 1 and POME 2

\begin{tabular}{cccc}
\hline Samples & N/P Ratio & $\boldsymbol{R}_{\boldsymbol{N}}\left(\mathbf{m g ~ g}^{\mathbf{- 1}} \mathbf{d}^{\mathbf{- 1}}\right)$ & $\boldsymbol{R}_{\boldsymbol{P}}\left(\mathbf{m g ~ g}^{\mathbf{- 1}} \mathbf{d}^{-\mathbf{1}}\right)$ \\
\hline POME 1 & 8.96 & 29.42 & 3.41 \\
POME 2 & 2.27 & 4.64 & 1.18 \\
\hline
\end{tabular}

The specific ammonium removal rates, $R_{N}$ for $C$. vulgaris grown in POME 1 and POME 2 were 29.42 and $4.64 \mathrm{mg} \mathrm{g}^{-1} \mathrm{~d}^{-1}$ with initial ammonium concentration (POME $1=167 \mathrm{mg} / \mathrm{L}$, POME $2=22.6 \mathrm{mg} / \mathrm{L})$. These results showed that high $R_{N}$ was achieved when initial concentration of ammonium introduced was high. These results were in agreement with a previous study whereby the specific $\mathrm{N}$ removal rates of Chlorella sp. grown in media with 9 and $56 \mathrm{~N} / \mathrm{P}$ were 1.8 and $3.8 \mathrm{mg} \mathrm{mg}^{-1} \mathrm{Chl} \mathrm{a} \mathrm{d}^{-1}$ respectively [12]. Furthermore, the other study observed that the specific $\mathrm{N}$ removal rates increased from 0.5 to $3 \mathrm{mg} \mathrm{mg}^{-1} \mathrm{Chl} \mathrm{a} \mathrm{d}^{-1}$ when the initial concentration of $\mathrm{NH}_{4}{ }^{+}-\mathrm{N}$ increased from $13.2 \mathrm{mg} / \mathrm{L}$ to $410 \mathrm{mg} / \mathrm{L}$ in synthetic wastewater [12].

In this study, a similar pattern of results was obtained for specific phosphorus removal rates, $R_{P}$. The $R_{P}$ increased from 1.18 to $3.41 \mathrm{mg} \mathrm{g}^{-1} \mathrm{~d}^{-1}$ with the increase of phosphorus initial concentration from 9.96 to $18.06 \mathrm{mg} / \mathrm{L}$. Slightly higher P concentration in the primary effluent also led to higher $R_{P}$. Chlorella $s p$. obtained 0.25 and $0.15 \mathrm{mg} \mathrm{mg}^{-1} \mathrm{Chl} \mathrm{a} \mathrm{d}$-1 for the diluted sludge centrate and the primary effluent with initial P, 4.0 and $3.5 \mathrm{mg} / \mathrm{L}$ respectively [12].

First-order and second-order reactions were tested for both nutrients removal to find the reaction constant. The reaction constant for first-order and second-order was calculated by Eq (2) and (3), respectively [13]. 


$$
\begin{aligned}
& -\ln \frac{C_{N}}{C_{N O}}=k t \\
& -\ln \frac{C_{P} C_{N O}}{C_{N} C_{P O}}=\left(C_{P O}-C_{N O}\right) k t
\end{aligned}
$$

where $C_{N}$ or $C_{P}$ and $C_{N O}$ or $C_{P O}$ represent the concentration of ammonium or phosphorus at time $t$ and $t_{o}$, respectively and $k$ is the reaction constant. Graphs were plotted for both order reactions and in this study, the removal of phosphorus and ammonium fitted most to the first-order reaction since $R^{2}$ in first-order reaction for both POME were higher than $R^{2}$ in second-order reaction, as shown in Table 4. This result was in line with a study that reported that the phosphorus and nitrogen removal in their study fitted the first-order reaction very well [12]. Based on the nutrient consumption, the yield of biomass was determined by Eq. (4), [11].

$$
Y=\frac{X_{i}-X_{0}}{C_{0}-C_{i}}
$$

where $Y$ represents the yield of biomass linked to the consumption of nutrients (phosphorus, $\mathrm{P}$ or ammonium, N), $C_{0}$ is the initial nutrient concentration, $C_{i}$ is the concentration of nutrients when there was no significant decrease of nutrients, $X_{i}$ represents $C$. vulgaris cell density with respect to the nutrient $C_{i}$ and $X_{0}$ is the initial $C$. vulgaris cell density [11]. The yield of biomass based on specific nutrient consumption and first order reaction rate constants are shown in Table 5.

Table 4: Value of $R^{2}$ for first and second order reaction

\begin{tabular}{cccc}
\hline Sample & \multicolumn{2}{c}{ First-Order } & Second-Order \\
\cline { 2 - 4 } & $R^{2}, P$ & $R^{2}{ }_{N}$ & $R^{2}{ }_{N P}$ \\
\hline POME 1 & 0.9305 & 0.9565 & 0.9231 \\
POME 2 & 0.8741 & 0.9127 & 0.8052 \\
\hline
\end{tabular}

Table 5: Kinetics parameters of nutrients removal for C. vulgaris in POME 1 and POME 2

\begin{tabular}{cccccc}
\hline Sample & $\boldsymbol{k} \boldsymbol{P}$ & $\boldsymbol{k}_{\boldsymbol{N}}$ & $\boldsymbol{Y}_{\boldsymbol{N}}$ & $\boldsymbol{Y}_{\boldsymbol{P}}$ & $\boldsymbol{Y}_{\boldsymbol{P}} / \boldsymbol{Y}_{\boldsymbol{N}}$ \\
\hline POME 1 & 0.3685 & 0.3272 & 0.01406 & 0.1213 & 8.6231 \\
POME 2 & 0.1271 & 0.1383 & 0.1751 & 0.6886 & 3.9327 \\
\hline
\end{tabular}

The biomass yield based on $\mathrm{N}$ consumption, $Y_{N}$, for $C$. vulgaris cultivated in POME 1 was lower than the yield in POME 2 which were $0.01406 \mathrm{~g} \mathrm{mg}^{-1} \mathrm{~N}$ and $0.1751 \mathrm{~g} \mathrm{mg}^{-1} \mathrm{~N}$ respectively. A similar result was obtained for $Y_{P}, 0.1213 \mathrm{~g} \mathrm{mg}^{-1} \mathrm{P}$ and $0.6886 \mathrm{~g} \mathrm{mg}^{-1} \mathrm{P}$ for C. vulgaris grown in POME 1 and POME 2, respectively. The ratio of $Y_{P} / Y_{N}$, indicates the amount of the ratio of N/P required ( $\mathrm{mg} \mathrm{N}$ consumed/mg P consumed) to produce the same unit amount of biomass. In this study, N/P ratio of POME 1 was almost double the N/P ratio of POME 2. Theoretically, the chemical formula of microalgae is $\mathrm{C}_{106} \mathrm{H}_{181} \mathrm{O}_{45} \mathrm{~N}_{16} \mathrm{P}$ where $\mathrm{N} / \mathrm{P}$ ratio is 7.2 [14]. The $Y_{P} / Y_{N}$ for $C$. vulgaris cultivated in POME 1 was 8.62, which is close to this theoretical value.

In this study, the final $\mathrm{N}$ and $\mathrm{P}$ concentration in POME 1 were 25.9 and $2.3 \mathrm{mg} / \mathrm{L}$ respectively. This case was similar to the result obtained by a study that stated that $\mathrm{P}$ was the limiting nutrient for microalgae grown in POME 1. Thus, the kinetic coefficients of 
microalgae growing in POME 1 were determined using Lineweaver-Burk equation (Eq. (5)), where $\mu$ is specific growth rate $\left(\mathrm{d}^{-1}\right), \mu_{\max }$ is the maximum specific growth rate $\left(\mathrm{d}^{-1}\right), \mathrm{S}$ is the concentration of limiting nutrient $(\mathrm{mg} / \mathrm{L})$ and $k_{s}$ is half-saturation coefficient $(\mathrm{mg} / \mathrm{L})$. Experimental data were plotted as illustrated in Fig. 3 [11].

$$
\frac{1}{\mu}=\frac{k_{S}}{\mu_{\max }} \frac{1}{S}+\frac{1}{\mu_{\max }}
$$

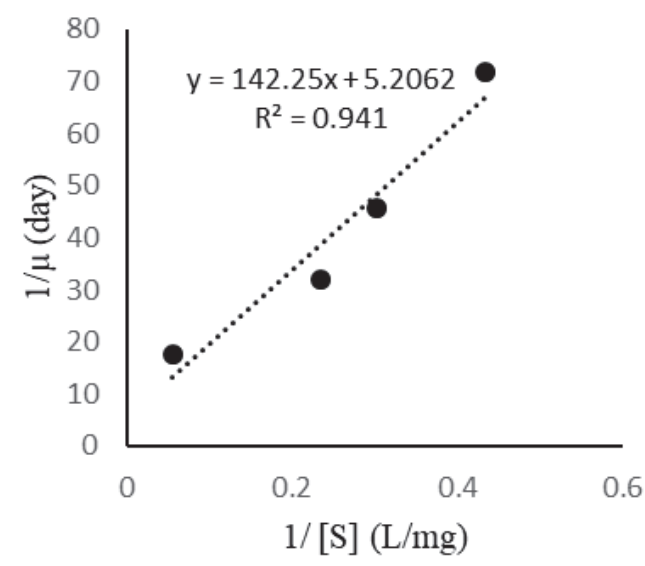

Fig. 3: Lineweaver-Burk plot used to estimate kinetic coefficient.

Based on the linear fit line for this plot (Fig. 3), the kinetic coefficients $\mu_{\max }$ and $k_{s}$ of $\mathrm{P}$ removal by $C$. vulgaris were determined to be $\mu_{\max }=0.192 \mathrm{~d}^{-1}$ and $\mathrm{k}_{s}=27.32 \mathrm{mg} / \mathrm{L}$ $\left(R^{2}=0.973\right)$.

\section{CONCLUSION}

As a conclusion, higher removal of ammonium from POME was obtained under aeration conditions $(73.5 \%)$ compared to that of agitation conditions $(34.4 \%)$. In addition, the microalgae - bacteria co-culture system showed higher removal of ammonium, phosphorus, and COD in POME (84\%, 87.3\% and 51.8\%, respectively) compared to that in the axenic microalgae system $(67 \%, 84.2 \%$ and $41.1 \%$, respectively). The kinetic coefficients obtained were $\mu_{\max }=0.192 \mathrm{~d}^{-1}$ and $\mathrm{k}_{\mathrm{s}}=27.32 \mathrm{mg} / \mathrm{L}$. The obtained data showed that this co-culture system has the potential to improve the current aerobic digestion process in the wastewater treatment. The long HRT required by the aerobic treatment can be shortened by replacing or integrating with this co-culture system. Moreover, this system also promotes green technology and can be considered for future commercial use. However, for COD removal, further investigation on POME treatment is required in order to achieve the standard set by DOE, Malaysia, prior to discharge into the river.

\section{ACKNOWLEDGMENT}

This research was supported by Research Initiative Grant Scheme (RIGS15-144-0144) from the International Islamic University Malaysia and Ministry of Higher Education, Malaysia.

\section{REFERENCES}

[1] Kamyab H, Fadhil M, Keyvanfar A, Abd MZ. (2015) Efficiency of Microalgae Chlamydomonas on the Removal of Pollutants from Palm Oil Mill Effluent (POME). Energy Procedia, 75: 2400-2408.

[2] Hadiyanto, Marcelinus C, Danny S. (2013) Phytoremediation of Palm Oil Mill Effluent 
(POME) by Using Aquatic Plants and Microalgae for Biomass Production, J. Environ. Sci. Technol., 6(2): 79-90.

[3] De-Bashan LE, Hernandez JP, Morey T, Bashan Y. (2004) Microalgae growth-promoting bacteria as 'helpers' for microalgae: A novel approach for removing ammonium and phosphorus from municipal wastewater. Water Res., 38(2): 466-474.

[4] Hernandez J, Luz E, Bashan Y. (2006) Starvation enhances phosphorus removal from wastewater by the with Azospirillum brasilense. Enzyme Microb. Technol, 38: 190-198.

[5] Mujtaba G, Rizwan M, Lee K. (2015) Simultaneous removal of inorganic nutrients and organic carbon by symbiotic co-culture of Chlorella vulgaris and Pseudomonas putida. Biotechnol. Bioprocess Eng., 20(6): 1114-1122.

[6] Delgadillo-mirquez L, Lopes F, Taidi B, Pareau D. (2016) Nitrogen and phosphate removal from wastewater with a mixed microalgae and bacteria culture. Biotechnol. Reports, 11: 1826.

[7] Samsudin A, Azmi AS, Mohd Nawi MN, Abdul Halim A. (2018) Wastewater treatment by microalgae-bacteria co-culture system. Malays. J. Microbiol., 14(2): 131-136.

[8] APHA. (1999) Standard Methods for the Examination of Water and Wastewater Part 4000 Inorganic Nonmetallic Constituents Standard Methods for the Examination of Water and Wastewater.

[9] Gonzalez LE, Bashan Y. (2000) Increased growth of the microalga Chlorella vulgaris when coimmobilized and cocultured in alginate beads with the plant-growth-promoting bacterium Azospirillum brasilense. Appl. Environ. Microbiol., 66(4): 1527-1531.

[10] Hariz HB, Takriff MS. (2017) Growth and Biomass Production of Native Microalgae Chlorella sp ., Chlamydomonas sp . and Scenedesmus sp . Cultivated in Palm Oil Mill Effluent (POME) at Different Cultivation Conditions. Transactions on Science and Technology, 4(3): 298-311.

[11] Wang M, Kuo-Dahab WC, Dolan S, Park C. (2014) Kinetics of nutrient removal and expression of extracellular polymeric substances of the microalgae, Chlorella sp. in wastewater treatment. Bioresour. Technol., 154: 131-137.

[12] Aslan S , Kapdan IK. (2006) Batch kinetics of nitrogen and phosphorus removal from synthetic wastewater by algae. J. Ecol. Eng., 8: 64-70.

[13] Levenspiel, O. (1999). Interpretation of Batch Reactor Data. (3rd ed.) In : Chemical Reaction Engineering (pp.38-63). New York, USA: John Wiley \& Sons.

[14] Grobbelaar, JU. (2007). Algal Nutrition - Mineral Nutrition, Amos, R. (1st ed.) In : Handbook of Microalgae Culture (pp. 95-115). New Jersey, USA: Blackwell Publishing Ltd. 